Kelola

Jurnal Manajemen Pendidikan

Magister Manajemen Pendidikan

ISSN 2443-0544

FKIP Universitas Kristen Satya Wacana

jurnalkelola@gmail.com

Volume: 3, No. 2, Juli-Desember 2016

Halaman: 277-293

\title{
EVALUASI PROGRAM TUNJANGAN PROFESI GURU DI SMP NEGERI KABUPATEN KENDAL
}

\author{
Akhmad Yantono \\ Alumni Program Pascasarjana Magister Manajemen Pendidikan \\ FKIP - Universitas Kristen Satya Wacana \\ yantonokendal@yahoo.co.id
}

\begin{abstract}
This study aimed to evaluate the level of achievement of teachers' professional allowance goal in SMP Negeri 1 Pageruyung Kendal. This study useds a goaloriented evaluation models developed by Ralph Winfred Tyler. Data were collected through interviews, questionnaires, observation, documentation and triangulation to ensure the validity of the data. Source of data was from the principal, teachers and students. Data were analyzed using qualitative analysis. The results showed that teachers' professional allowance in SMP Negeri 1 Pageruyung: 1) has been able to raise the dignity of teachers, although the elements of scientific research has not been done by all teachers, and done only by one teacher. 2) has been able to improve the competence of teachers, although the elements of time management in the classroom has not been effective; the element of teachers questioning skill was not maximum; and the elements of evaluation, assessment tools have not been developed in accordance with the purpose of learning. 3) have not been able to advance the teachers professional because the teachers thoughts has not been communicated yet in the environment of the school and scientific forums. 4) has been able to improve the quality of learning, although in the assessment, teachers have not provided written comments on the test results, and has not given an assignment to write or read the related materials that have been learned. 5) has been able to improve the quality education services for learners.
\end{abstract}

Keywords: program evaluation, teachers' professional allowance, goal-oriented evaluation models

\section{PENDAHULUAN}

Banyak upaya yang telah dilakukan oleh pemerintah untuk meningkatkan kualitas pendidikan, diantaranya adalah dengan meningkatkan kualitas guru. Hal ini dapat dimengerti karena kualitas sistem pendidikan berkaitan erat dengan kualitas guru (Amat Jaedun, 2009). Oleh karena itu, dimasa sekarang ini pengakuan dan penghargaan terhadap profesi guru semakin meningkat, yang ditandai dengan lahirnya Undang-undang Nomor 14 Tahun 2005, tentang Guru dan Dosen.

Pengakuan kedudukan guru sebagai tenaga profesional dibuktikan dengan cara melakukan sertifikasi bagi guru dalam jabatan. Kemudian guru yang telah memiliki sertifikat pendidik berhak memperoleh penghasilan di atas kebutuhan hidup minimum dan 
jaminan kesejahteraan sosial, terdiri dari gaji pokok, tunjangan yang melekat gaji, dan termasuk tunjangan profesi.

Tunjangan profesi guru merupakan tunjangan yang diberikan kepada guru yang memiliki sertifikat pendidik. Tunjangan profesi dimaksudkan untuk peningkatan mutu guru sebagai penghargaan atas profesionalitas untuk mewujudkan amanat UndangUndang Guru dan Dosen antara lain mengangkat martabat guru, meningkatkan kompetensi guru, memajukan profesi guru, dan meningkatkan mutu pembelajaran, serta meningkatkan pelayanan pendidikan yang bermutu (Kemdikbud, 2013).

Tunjangan profesi guru merupakan tunjangan yang diberikan kepada guru yang memiliki sertifikat pendidik. Tunjangan profesi dimaksudkan untuk peningkatan mutu guru sebagai penghargaan atas profesionalitas untuk mewujudkan amanat UndangUndang Guru dan Dosen antara lain mengangkat martabat guru, meningkatkan kompetensi guru, memajukan profesi guru, dan meningkatkan mutu pembelajaran, serta meningkatkan pelayanan pendidikan yang bermutu (Kemdikbud, 2013).

Martabat guru menurut Supriyoko (2006), merupakan gambaran tingkatan harkat kemanusiaan dan kedudukan guru yang terhormat. Menurut Arni Muhammad (2005), sebagai profesi, seorang guru selain memahami harkat dan martabat guru, juga harus memahami norma yang harus dipedomani dan dipatuhi yakni kode etik guru. Martabat guru tercermin pada kode etik guru. Kode etik ini bertujuan menempatkan guru sebagai profesi yang terhormat, mulia, bermartabat dan dilindungi undang-undang (Sudarwan, 2012).

Kompetensi guru berdasarkan Peraturan Pemerintah (PP) Nomor 74 Tahun 2008 diartikan sebagai seperangkat pengetahuan, keterampilan, dan perilaku yang harus dimiliki, dihayati, dikuasai, serta diaktualisasikan oleh guru dalam melaksanakan tugas keprofesionalannya. Sedangkan kompetensi yang perlu dimiliki setiap guru meliputi kompetensi pedagogik, kompetensi kepribadian dan kompetensi sosial serta kompetensi profesional, yang harus diperoleh melalui pendidikan profesi.

Undang-Undang Nomor 20 Tahun 2003 tentang Sistem Pendidikan Nasional, menyebutkan bahwa jabatan guru sebagai pendidik merupakan jabatan profesional. Sedangkan sebagai suatu profesi menurut Arni Muhammad (2005) guru harus memiliki organisasi profesi yang dapat dijadikan tempat bagi guru untuk memperjuangkan hakhaknya dan juga untuk meningkatkan profesionalismenya. 
Kualitas pembelajaran merupakan ukuran yang menunjukkan seberapa tinggi kualitas interaksi guru dengan siswa dalam proses pembelajaran dalam rangka pencapaian tujuan tertentu (Depdiknas, 2004). Morrison, Mokashi \& Cotter dalam Eko Putro Widoyoko (2009) dalam risetnya telah merumuskan 44 indikator kualitas pembelajaran yang direduksi kedalam sepuluh indikator, yaitu: 1) Lingkungan fisik mampu menumbuhkan semangat siswa untuk belajar; 2) Iklim kelas kondusif untuk belajar; 3) Guru menyampaikan pelajaran dengan jelas dan semua siswa mempunyai keinginan untuk berhasil; 4) Guru menyampaikan pelajaran secara sistematis dan terfokus; 5) Guru menyajikan materi dengan bijaksana; 6) Pembelajaran bersifat riil (autentik dengan permasalahan yang dihadapi masyarakat dan siswa); 7) Ada penilaian diagnostik yang dilakukan secara periodik ; 8) Membaca dan menulis sebagai kegiatan yang esensial dalam pembelajaran; 9) Menggunakan pertimbangan yang rasional dalam memecahkan masalah; 10) Menggunakan teknologi pembelajaran, baik ketika mengajar maupun untuk kegiatan belajar siswa.

Pelayanan pendidikan yang bermutu, menurut Ikke Dewi Sartika (2002), merupakan pemberian layanan jasa pendidikan di sekolah yang dapat memberikan kepuasan kepada para siswa di sekolah dan masyarakat atau orang tua siswa. Menurut Dedi Supriadi (1999), guru ideal harus mampu memberikan pelayanan pendidikan yang bermutu bagi siswa dengan bertindak sebagai pelatih, konselor, dan manajer belajar.

Pertanyaan yang muncul adalah apakah tujuan pemberian tunjangan profesi guru selama ini telah tercapai ? Beberapa penelitian yang telah dilakukan dapat memberikan gambaran. Penelitian Badrun Kartowagiran (2011), tentang Kinerja Guru Profesional Pasca Sertifikasi, menyimpulkan bahwa kinerja sebagian guru profesional di kabupaten Sleman belum baik. Sementara itu hasil penelitian Evaluasi Program Kegiatan Kelompok Kerja Guru Madrasah Ibtidaiyah (KKG-MI) Cemara Jaya di Lingkungan Kemenag Kabupaten Halmahera Timur, oleh Yamin Latief Tjokra pada tahun 2011, menunjukkan bahwa kompetensi paedagogik dan kompetensi profesional guru-guru Madrasah Ibtidaiyah masih pada taraf sedang. Lebih lanjut penelitian yang dilakukan oleh Yasbiati (2010) mengenai pengaruh persepsi guru tentang sertifikasi terhadap kualitas pembelajaran, menyimpulkan bahwa terdapat hubungan antara persepsi guru tentang sertifikasi dengan kualitas pembelajaran di SD Negeri Nagarawangi 1 Tasikmalaya. Di luar negeri penelitian yang dilakukan oleh Lyimo (2014) mengungkapkan bahwa gaji guru 
sekolah dasar di Tanzania yang tidak cukup dan tertundanya pembayaran tunjangan guru menyebabkan guru-guru melakukan aktivitas tambahan diluar mengajar sehingga berdampak pada kacaunya aktivitas pembelajaran. Sedang penelitian yang dilakukan Meke (2013), menyimpulkan bahwa di Malawi, bahwa sedikitnya tunjangan guru menyebabkan kurangnya pelayanan guru.

Fenomena yang kurang lebih sejalan juga terjadi di SMP Negeri 1 Pageruyung Kabupaten Kendal. Pada tahun pelajaran 2013/2014, hasil verifikasi penilaian kinerja pasca sertifikasi oleh pengawas SMP tahun 2014, diketahui bahwa tidak semua guru di SMP Negeri 1 Pageruyung yang telah menerima tunjangan profesi berkinerja Amat Baik. Dari 23 guru penerima tunjangan profesi, yang mendapatkan skor kinerja Amat Baik sebanyak 10 orang, mendapatkan skor Baik sebanyak 13 orang (Margana, 2014). Idealnya sebagai penerima tunjangan profesi, guru-guru tersebut mendapatkan skor kinerja Amat Baik, karena tunjangan profesi tersebut seharusnya mendukung peningkatan kompetensi mereka. Demikian juga untuk target menaikkan rata-rata nilai Ujian Nasional (UN) Tahun Pelajaran 2013/2014 tidak tercapai, karena ditargetkan 6,9 tetapi dicapai hanya 6,5. Sebagai penerima tunjangan profesi, guru-guru SMP Negeri 1 Pageruyung seharusnya dapat meningkatkan kualitas pembelajarannya, sehingga target-target akademik sekolah dapat dicapai. Oleh karena itu penulis tertarik untuk melakukan evaluasi terhadap program pemberian tunjangan profesi guru di SMP Negeri 1 Pageruyung.

Suharsimi Arikunto (2007) mendefinisikan evaluasi program sebagai suatu proses penetapan secara sistematis mengenai nilai, tujuan, dan efektifitas atau kecocokan sesuatu sesuai dengan kriteria dan tujuan yang telah ditetapkan sebelumnya. Dalam ilmu evaluasi program pendidikan, terdapat beberapa model yang dapat digunakan untuk mengevaluasi keterlaksanaan program. Stepphen Isaac dalam Suharsimi (2007) membedakan adanya empat hal yang dipergunakan untuk membedakan ragam model evaluasi, yaitu : 1) berorientasi pada tujuan (goal oriented); 2) berorientasi pada keputusan (decision oriented); 3) berorientasi pada kegiatan dan orang - orang yang menanganinya (transactional oriented) dan 4) berorientasi pada pengaruh dan dampak program (research oriented). Penelitian ini menggunakan Model Evaluasi Program Berorientasi Tujuan (Goal Oriented Evaluation Model) yang dikembangkan oleh Ralph Winfred Tyler. Tyler mendefinisikan evaluasi sebagai perbandingan antara hasil yang dikehendaki dengan hasil yang sebenarnya. Dalam model ini, langkah pertama adalah mengenali tujuan suatu 
program. Setelah tujuan program diketahui, indikator-indikator pencapaian tujuan dan alat pengukuran diketahui pasti. Kemudian dari hasil kajian tersebut akan dibandingkan dengan tujuan program dan keputusan dibuat level pencapaian yang diperoleh

Sejalan dengan latar belakang masalah di atas maka rumusan masalah dalam penelitian ini adalah bagaimana ketercapaian tujuan pemberian tunjangan profesi di SMP Negeri 1 Pageruyung Kabupaten Kendal. Dengan demikian penelitian ini bertujuan untuk mengevaluasi ketercapaian tujuan pemberian tunjangan profesi guru di SMP Negeri 1 Pageruyung. Secara teoritis penelitian ini diharapkan dapat bermanfaat menambah wawasan dan pengetahuan bagi penyelenggara pendidikan, dan dapat dijadikan referensi bagi penelitian selanjutnya yang berkaitan dengan program tunjangan profesi guru. Sedangkan secara praktis hasil penelitian ini dapat digunakan sebagai bahan pertimbangan oleh kepala sekolah untuk pengambilan keputusan selanjutnya terkait dengan program tunjangan profesi guru di SMP Negeri 1 Pageruyung dan bagi guru dapat dijadikan sebagai bahan evaluasi diri terkait dengan tunjangan profesi guru.

\section{METODE PENELITIAN}

Penelitian ini adalah penelitian evaluatif dengan model evaluasi berorientasi pada tujuan (goal-oriented) yang dikembangkan oleh Ralph Winfred Tyler. Teknik pengumpulan datanya menggunakan wawancara, angket dan dokumentasi. Wawancara semistruktur (semistructure interview) dilakukan kepada kepala sekolah. Angket diberikan kepada 50 siswa dan 22 guru. Dokumentasi dilakukan melalui pengumpulan data resmi di SMP Negeri 1 Pageruyung. Uji validitas dan reliabilitas angket dilakukan di SMP Negeri 1 Plantungan Kabupaten Kendal pada tanggal 9 Pebruari 2015 terhadap 48 siswa. Pengujian validitas menggunakan teknik korelasi product moment, sedangkan uji reliabilitasnya menggunakan teknik analisis Alpha Cronbach.

Analisis data menggunakan analisis kualitatif. Sedangkan tahap analisis data menggunakan pendapat Moleong (2004), yaitu: a) Pengumpulan data, b) Reduksi data, c) Penyajian data, dan d) Penarikan kesimpulan. Triangulasi data menggunakan triangulasi teknik dan triangulasi sumber. Hal tersebut dicapai dengan jalan: 1) Membandingkan data dari hasil wawancara dengan data angket; 2) Membandingkan data hasil wawancara dengan isi suatu dokumen yang berkaitan.

\section{HASIL DAN PEMBAHASAN}


SMP Negeri 1 Pageruyung beralamat di Jalan Raya Bogosari, Dusun Bogosari, Desa Tambahrejo, Kecamatan Pageruyung, Kabupaten Kendal. Lokasi SMP Negeri 1 Pageruyung berada di daerah perbukitan (429 dpl.), yang berjarak kurang lebih 40 kilometer dari pusat ibukota Kabupaten Kendal. Sekolah ini berdiri pada tahun 1980, sesuai Surat Keputusan Pemerintah Nomor 0206/0/1980, Tanggal 30 Juli 1980. Sedangkan nilai akreditasi sekolah terakhir pada tahun 2013 adalah A. Sekolah ini memiliki visi "Imtaq Melekat, Prestasi Meningkat, Terampil dan Memikat".

Pada tahun pelajaran 2014/2015 ini, SMP N 1 Pageruyung memiliki peserta didik berjumlah 545 siswa, yang terbagi kedalam 18 rombongan belajar. Berdasarkan identifikasi dokumen sekolah, diketahui dari 29 guru yang berstatus PNS, sebanyak 22 guru telah memiliki sertifikat profesi dan mereka semua telah menerima tunjangan profesi.

Mengacu pada tujuan pemberian tunjangan profesi, maka pembahasan evaluasi hasil penelitian akan didasarkan pada hasil analisis wawancara dengan kepala SMP Negeri 1 Pageruyung, hasil analisis data persepsi siswa terhadap guru penerima tunjangan profesi dan analisis data kuesioner guru penerima tunjangan profesi

\section{Evaluasi Terhadap Martabat Guru SMP Negeri 1 Pageruyung}

Guru - guru di SMP Negeri 1 Pageruyung disamping tugas pokoknya sebagai pengajar, ternyata mereka telah membimbing agar para siswa memiliki kepribadian yang baik, dimana pembimbingan tersebut diantaranya melalui program-program pembiasaan yang ada di sekolah. Kegiatan ini menunjukkan bahwa guru-guru di SMP Negeri 1 Pageruyung telah memahami kode etik guru, terutama kesadaran bahwa mereka harus berbakti membimbing para peserta didik untuk membentuk manusia seutuhnya sesuai dengan jiwa pancasila.

Pada waktu melaksanakan pembelajaran, guru-guru SMP Negeri 1 Pageruyung telah bersikap adil, dimana tidak pernah ada laporan dari siswa tentang adanya guru yang membeda-bedakan latar belakang atau kedudukan orang tua siswa ketika mereka mengajar. Berkaitan dengan hal itu, berarti guru-guru SMP Negeri 1 Pageruyung telah memiliki dan melaksanakan kejujuran profesional, sesuai dengan kode etik guru, dimana guru harus menghargai dan memperhatikan perbedaan dan kebutuhan peserta didiknya masing-masing.

Selama ini guru - guru SMP Negeri 1 Pageruyung dalam berkomunikasi dengan siswa telah fokus pada kepentingan pendidikan siswa. Hal ini berarti guru telah berusaha 
memperoleh informasi tentang peserta didik sebagai bahan melakukan bimbingan dan pembinaan. Berkaitan dengan peran guru sebagai pembaharu dalam kehidupan dan kemajuan di masyarakat sekitarnya, pada umumnya guru-guru telah menjadi agen pembaharu di masyarakat tempat tinggalnya. Guru-guru juga terlibat dalam kegiatan masyarakat, dengan menjadi pengurus di lembaga-lembaga sosial yang ada. Hal itu sesuai dengan kode etik guru, dimana guru harus berperan agar dirinya dan sekolahnya dapat berfungsi sebagai unsur pembaru bagi kehidupan dan kemajuan daerahnya, dan turut serta bersama - sama masyarakat sekitarnya di dalam berbagai aktivitas.

Terkait bahwa guru itu harus senantiasa menambah dan memperluas ilmu, wawasan dan keterampilan-keterampilannya, guru-guru di SMP Negeri 1 Pageruyung telah melakukannya. Sedangkan untuk kegiatan ilmiah seperti seminar, workshop dan sejenisnya, guru-guru SMP Negeri 1 Pageruyung, banyak yang telah mengikutinya.

Berkaitan dengan kegiatan penelitian ilmiah, ternyata belum semua guru di SMP Negeri 1 Pageruyung melakukannya. Hal ini dikarenakan bahan bacaan guru dan kemampuan guru didalam menulis masih terbatas. Apabila didasarkan pada kode etik, maka guru seharusnya secara pribadi atau bersama - sama mengembangkan dan meningkatkan mutu dan martabat profesi, dengan jalan rajin membaca, melakukan penelitian, mengikuti seminar ilmiah, workshop, penataran dan kegiatan keilmuan lainnya.

Terkait dengan guru dalam kesehariannya harus saling bertukar informasi, telah dilakukan oleh guru-guru SMP Negeri 1 Pageruyung melalui kegiatan MGMP sekolah. Hal ini sesuai dengan kode etik guru dimana guru perlu memelihara hubungan seprofesi, semangat kekeluargaan, serta kesetiakawanan sosial, dengan saling bertukar informasi, mengemukakan pendapat, saling nasehat menasehati dan bantu membantu satu sama lainnya, baik didalam hubungan kepentingan pribadi maupun dalam menunaikan tugas profesinya.

Kemudian terkait dengan guru harus patuh dan tunduk terhadap kebijakan pemerintah, guru-guru SMP Negeri 1 Pageruyung telah menjalankannya, misalnya kebijakan pemerintah tentang sekolah-sekolah yang baru melaksanakan kurikulum 2013 selama satu semester agar kembali ke KTSP 2006, dapat dipahami oleh guru-guru. Hal itu 
sesuai dengan kode etik, dimana guru harus melaksanakan semua kebijakan pemerintah dalam bidang pendidikan.

Berdasarkan analisis data kuesioner siswa, dapat diketahui bahwa kategori hasil pengukuran aspek martabat guru menunjukkan sebanyak 42 sampel berada pada kategori sangat tinggi (84\%), dan kategori tinggi memiliki nilai sebesar $16 \%$ dengan $n=8$. Sedangkan berdasarkan analisis data kuesioner guru, diketahui bahwa kategori hasil pengukuran aspek martabat guru menunjukkan 22 sampel (100\%) berada pada kategori sangat tinggi.

Berdasarkan hasil wawancara dan hasil angket tersebut diatas, maka dapat dikatakan bahwa tujuan program tunjangan profesi guru untuk mengangkat martabat guruguru SMP Negeri 1 Pageruyung sudah tercapai, meskipun masih ada tindakan-tindakan guru yang belum maksimal terpenuhi, yaitu tindakan untuk melakukan penelitian ilmiah.

\section{Evaluasi Terhadap Kompetensi Guru SMP Negeri 1 Pageruyung}

Terkait dengan karakteristik belajar setiap peserta didik, guru-guru SMP Negeri 1 Pageruyung sudah dapat mengenali dan mengidentifikasinya. Guru-guru melakukan identifikasi karakter siswa dengan cara memberi kesempatan yang sama untuk berpartisipasi dalam pembelajaran. Keadaan ini sesuai dengan kompetensi pedagogik guru dimana guru harus menguasai karateritistik peserta didik, seperti tertuang didalam Peraturan Pemerintah Nomor 19 Tahun 2005.

Terkait dengan pengajaran, guru-guru SMP Negeri 1 Pageruyung telah memberikan respon kepada peserta didik yang belum atau kurang memahami pelajaran yang diajarkan, sehingga dari apa yang belum diketahui ini guru dapat memperbaiki perancangan pembelajaran selanjutnya, dimana perbaikan pembelajaran itu didasarkan pada kegiatan analisis ulangan harian. Hal ini sesuai dengan tuntutan agar guru menguasai teori belajar dan prinsip-prinsip pembelajaran yang mendidik seperti tertuang dalam Peraturan Pemerintah Nomor 19 Tahun 2005.

Dalam merancang Rencana Pelaksanaan Pembelajaran (RPP), guru - guru SMP Negeri 1 Pageruyung telah menyesuaikan dengan silabus. Hal ini sesuai dengan Peraturan Pemerintah Nomor 19 Tahun 2005, dimana guru harus mengembangkan kurikulum yang meliputi penyusunan silabus yang sesuai dengan kurikulum, perancangan rencana pembelajaran yang sesuai dengan silabus dan mengikuti urutan materi pembelajaran dengan memperhatikan tujuan pembelajaran. 
Pada aktivitas pembelajaran, guru-guru SMP Negeri 1 Pageruyung telah melaksanakan pembelajaran sesuai dengan rancangan yang sudah disusun, akan tetapi berkaitan dengan manajemen waktu pembelajaran di kelas, guru belum bisa menggunakan dengan semestinya seperti yang tercantum dalam RPP. Seharusnya guru melaksanakan kegiatan pembelajaran yang mendidik, dan yang perlu dilakukan adalah melaksanakan aktivitas pembelajaran sesuai dengan rancangan yang telah disusun secara lengkap.

Dalam pelaksanaan pembelajaran, guru-guru SMP Negeri 1 Pageruyung telah mampu memusatkan perhatian, sehingga siswa dapat berinteraksi dengan baik. Hal ini ditunjang oleh adanya penggunaan berbagai metode mengajar oleh guru dengan tujuan agar interaksi berjalan dengan baik. Dalam hal ini guru harus mengembangkan potensi peserta didik dengan memusatkan perhatian pada interaksi peserta didik dan mendorongnya untuk memahami dan menggunakan informasi yang disampaikan tersebut.

Sebagian guru-guru SMP Negeri 1 Pageruyung telah melakukan penggalian pemahaman siswa dengan menggunakan pertanyaan - pertanyaan, sehingga siswa kemudian dapat menjawab dengan gagasannya sendiri. Meskipun demikian ada beberapa guru yang masih harus diberikan pengarahan oleh kepala sekolah agar ketrampilan bertanyanya menjadi lebih baik. Hal ini berkaitan dengan guru harus mampu berkomunikasi terhadap peserta didik dan menggunakan pertanyaan untuk mengetahui pemahaman dan menjaga partisipasi peserta didik, termasuk diantaranya adalah memberikan pertanyaan terbuka yang menuntut peserta didik untuk menjawab dengan ide dan pengetahuan mereka.

Dalam melakukan penilaian, belum semua guru SMP Negeri 1 Pageruyung menyusun alat penilaian yang sesuai dengan tujuan pembelajaran yang sudah ditetapkan. Berdasarkan pengamatan dari kepala sekolah diketahui bahwa ada guru-guru yang alat penilaiannya sudah sesuai dengan tujuan pembelajaran, akan tetapi sebagian besar guru belum sesuai. Sesuai dengan Peraturan Pemerintah Nomor 19 Tahun 2005, guru memang harus mampu melaksanakan penilaian dan evaluasi yaitu mampu menyusun alat penilaian yang sesuai dengan tujuan pembelajaran untuk mencapai kompetensi tertentu seperti yang tertulis dalam RPP.

Guru-guru SMP Negeri 1 Pageruyung telah mengembangkan kerjasama dan membina kebersamaan dengan teman sejawat. Meskipun guru-guru di SMP Negeri 1 
Pageruyung mayoritas muslim dan sebagian kecil non muslim, akan tetapi toleransi berjalan baik karena didasari oleh saling menghormati antar sesama. Kondisi ini terjadi, karena guru-guru telah bertindak sesuai dengan norma agama, hukum, sosial dan kebudayaan, dengan menghargai dan mempromosikan prinsip-prinsip Pancasila sebagai dasar ideologi dan etika bagi semua warga Indonesia.

Terkait dengan guru harus bersikap dewasa ketika mengajar, guru-guru SMP Negeri 1 Pageruyung telah memiliki sikap ini. Sikap dewasa ini ditunjukkan dengan cara guru bereaksi ketika menerima masukan-masukan dari peserta didik. Masukanmasukan tersebut diberikan secara tidak langsung, akan tetapi melalui kotak saran yang telah disediakan. Hal itu sesuai dengan Peraturan Pemerintah Nomor 19 Tahun 2005, dimana guru dianggap bersikap dewasa apabila guru senantiasa berlaku sopan dalam berbicara, berpenampilan, dan berbuat terhadap semua peserta didik, orang tua, dan teman sejawat.

Selama ini, guru-guru SMP Negeri 1 Pageruyung selalu meminta ijin dan memberitahu lebih awal, jika tidak dapat menghadiri kegiatan yang telah direncanakan, termasuk proses pembelajaran di kelas. Guru memang diwajibkan menyampaikan izin apabila tidak bisa melaksanakan tugas karena sesuatu hal, baik yang tidak terencana maupun yang sudah direncanakan. Kondisi ini menunjukkan bahwa guru-guru SMP Negeri 1 Pageruyung telah memiliki etos kerja, dan tanggung jawab yang tinggi, serta rasa bangga menjadi guru.

Guru-guru SMP N 1 Pageruyung telah ikut berperan aktif dalam kegiatan di luar pembelajaran yang diselenggarakan oleh sekolah dan masyarakat. Meskipun mereka sebagian besar adalah pendatang, tetapi guru-guru tersebut sudah menjadi warga lokal yang beradaptasi dengan lingkungannya. Mereka juga mendapatkan kepercayaan masyarakat, untuk menjadi pengurus di dalam organisasi-organisasi sosial kemasyarakatan yang ada dilingkungannya. Hal itu merupakan bentuk kompetensi sosial guru, dimana guru berperan aktif dalam kegiatan di luar pembelajaran yang diselenggarakan oleh sekolah dan masyarakat.

Guru-guru SMP Negeri 1 Pageruyung juga telah melakukan pemetaan Standar Kompetensi (SK) dan Kompetensi Dasar (KD) untuk mata pelajaran yang diampunya. Hal itu sesuai dengan Peraturan Pemerintah Nomor 19 Tahun 2005, dimana guru harus mampu melakukan pemetaan standar kompetensi dan kompetensi dasar untuk mata 
pelajaran yang diampunya, untuk mengidentifikasi materi pembelajaran yang dianggap sulit, melakukan perencanaan dan pelaksanaan pembelajaran, serta memperkirakan alokasi waktu yang diperlukan.

Terkait dengan penelitian ilmiah, masih sedikit guru-guru di SMP Negeri 1 Pageruyung yang melakukannya. Hal ini sesuai dengan informasi dari kepala sekolah yang mengatakan baru 1 orang guru yang telah melakukan penelitian tindakan kelas (PTK). Sedang kegiatan ilmiah yang banyak diikuti guru hanyalah seminar. Dalam hal ini guru dituntut untuk dapat mengembangkan keprofesionalan melalui tindakan yang reflektif, yang menurut Peraturan Pemerintah Nomor 19 Tahun 2005 antara lain guru harus melakukan penelitian, mengembangkan karya inovasi, mengikuti kegiatan ilmiah dan selalu aktif dalam melaksanakan PKB,

Berdasarkan analisis data kuesioner persepsi siswa, diketahui bahwa kategori hasil pengukuran aspek kompetensi guru menunjukkan sebanyak 45 sampel (90\%) berada pada kategori sangat tinggi, dan untuk kategori tinggi memiliki nilai sebesar $10 \%$ dengan $n=5$. Sedangkan berdasarkan analisis data kuesioner guru, diketahui bahwa kategori hasil pengukuran aspek kompetensi guru menunjukkan 16 sampel (73\%) berada pada kategori sangat tinggi. Sementara itu kategori tinggi memiliki nilai sebesar $27 \%$ dengan $n=6$.

Berdasarkan hasil wawancara dan hasil angket tersebut diatas, maka dapat dikatakan bahwa tujuan program tunjangan profesi guru untuk meningkatkan kompetensi guru-guru SMP Negeri 1 Pageruyung sudah tercapai, meskipun masih ada tindakantindakan yang belum maksimal, antara lain terkait dengan manajemen waktu pembelajaran di kelas yang belum efektif, belum baiknya ketrampilan bertanya guru, dan masih adanya beberapa guru yang alat penilaiannya belum sesuai dengan tujuan pembelajarannya.

\section{Evaluasi Terhadap Kemajuan Profesi Guru SMP Negeri 1 Pageruyung}

Berkaitan dengan guru harus mampu mengkomunikasikan pikirannya melalui kegiatan seminar, simposium dan sejenisnya, guru-guru SMP Negeri 1 Pageruyung belum pernah ada yang melakukan. Sesuai dengan pasal 41 Undang-Undang Nomor 14 Tahun 2005, guru seharusnya aktif mengkomunikasikan berbagai pikiran dan pengalaman yang mengarah kepada pembaharuan dan perbaikan mutu pendidikan, melalui seminar, simposium, dan sejenisnya, termasuk mengkomunikasikan secara tertulis dalam bentuk jurnal profesi atau media lainnya. 
Berdasarkan analisis data kuesioner siswa, dapat diketahui bahwa kategori hasil pengukuran aspek profesi guru menunjukkan 50 sampel (100\%) berada pada kategori sangat tinggi. Sedangkan berdasarkan analisis data kuesioner guru, dapat diketahui bahwa hasil pengukuran aspek profesi menunjukkan pada kategori rendah sejumlah 9 sampel (41\%), dan kategori sangat rendah sejumlah 13 sampel (59\%).

Berdasarkan hasil wawancara dan hasil angket tersebut diatas, maka dapat dikatakan bahwa tujuan program tunjangan profesi untuk memajukan profesi guru di SMP Negeri 1 Pageruyung belum tercapai. Hal ini terjadi karena para guru belum terbiasa mengkomunikasikan pemikiran-pemikirannya baik dilingkungan sekolah maupun di forum-forum ilmiah.

\section{Evaluasi Terhadap Mutu Pembelajaran di SMP Negeri 1 Pageruyung}

Lingkungan fisik dan suasana kelas di SMP Negeri 1 Pageruyung tergolong nyaman sebagai sarana pendukung keberhasilan pembelajaran siswa. Hal ini sesuai dengan pendapat Morrison, dkk. dalam Eko Putro (2009) yang menyatakan bahwa lingkungan fisik mampu menumbuhkan semangat siswa untuk belajar.

Guru-guru SMP Negeri 1 Pageruyung juga telah mampu memotivasi siswa agar mempunyai keinginan kuat untuk berhasil dalam belajarnya. Kendala justru muncul kadang-kadang dari pihak orang tua siswa yang sering kurang mendukung semangat belajar siswa.

Terkait dengan proses pembelajaran, guru-guru SMP Negeri 1 Pageruyung telah menyampaikan pelajaran secara sistematis dan terfokus. Hal ini sesuai dengan pendapat Morrison, dkk. dalam Eko Putro (2009) yang menyatakan bahwa salah satu indikator kualitas pembelajaran adalah guru menyampaikan pelajaran secara sistematis dan terfokus.

Guru-guru SMP Negeri 1 Pageruyung ketika mengajar telah bersikap bijaksana. Hal ini tercermin dari tindakan guru yang cenderung lebih sabar dan tidak lagi mengedepankan kekerasan fisik dalam pembelajaran.

Dalam mengajar guru-guru SMP Negeri 1 Pageruyung juga telah mengembangkan pembelajaran kontekstual yaitu mengaitkan dengan kondisi lingkungan kehidupan di mana siswa tinggal. Menurut Morrison, dkk. dalam Eko Putro (2009), bahwa pembelajaran yang bersifat riil atau autentik dengan permasalahan yang dihadapi masyarakat dan siswa yang disajikan oleh guru merupakan salah satu indikator adanya mutu pembelajaran. 
Dalam melakukan penilaian, masih sedikit guru-guru SMP Negeri 1 Pageruyung yang telah memberikan komentar tertulis pada ulangan atau tes yang diujikan pada siswa. Penyebab guru belum memberikan komentar tertulis pada ulangan atau tes tersebut, karena guru harus mengoreksi ulangan dalam jumlah banyak. Komentar tertulis itu penting karena terkait dengan penilaian diagnostik yang seharusnya dilakukan secara periodik oleh guru.

Dalam melaksanakan proses pembelajaran, belum semua guru SMP Negeri 1 Pageruyung memberikan tugas kepada siswa, untuk menulis atau membaca tentang apa yang telah dipelajari siswa, karena guru berpandangan bahwa pemberian tugas menulis atau membaca itu tergantung konteks di RPP. Menurut Morrison, dkk. dalam Eko Putro (2009) bahwa membaca dan menulis itu merupakan kegiatan yang esensial dalam pembelajaran.

Guru-guru SMP Negeri 1 Pageruyung belum semuanya memanfaatkan sarana pendukung pembelajaran yang ada di sekolah ketika mengajar, karena belum terpasangnya semua sarana pendukung pembelajaran tersebut di setiap ruang belajar yang ada, dengan pertimbangan keamanan. Menurut Depdiknas (2004) penggunaan teknologi pembelajaran, baik untuk mengajar maupun untuk kegiatan belajar siswa merupakan salah satu faktor pendukung keberhasilan proses pembelajaran, karena itu guru perlu mengupayakan dalam setiap pembelajaran yang dilakukan.

Berdasarkan analisis data kuesioner siswa, maka diketahui bahwa kategori hasil pengukuran aspek mutu pembelajaran guru menunjukkan 27 sampel berada pada kategori sangat tinggi (54\%). Sementara itu kategori tinggi memiliki nilai sebesar $44 \%$ dengan $\mathrm{n}=22$ dan kategori sedang 1 sampel. Sedangkan berdasarkan analisis data kuesioner guru, maka dapat diketahui bahwa kategori hasil pengukuran aspek mutu pembelajaran guru menunjukkan 9 sampel berada pada kategori sangat tinggi (41\%). Sementara itu kategori tinggi memiliki nilai sebesar 55\% dengan $n=12$ dan kategori sedang 1 sampel.

Berdasarkan hasil wawancara dan hasil angket tersebut diatas, maka dapat dikatakan bahwa tujuan program tunjangan profesi guru untuk meningkatkan mutu pembelajaran di SMP Negeri 1 Pageruyung sudah tercapai, meskipun masih ada beberapa kegiatan yang belum dilakukan oleh guru, yaitu belum semua guru memberikan komentar tertulis pada ulangan atau tes yang diujikan kepada siswa. Juga dalam melaksanakan proses pembelajaran, belum semua guru SMP Negeri 1 Pageruyung 
memberikan tugas kepada siswa, untuk menulis atau membaca tentang apa yang telah dipelajarinya.

\section{Evaluasi Terhadap Pelayanan Pendidikan Bermutu di SMP Negeri 1 Pageruyung}

Disamping mengajar, guru-guru SMP Negeri 1 Pageruyung juga telah melatih siswa, sehingga siswa merasa terbantu. Kegiatan melatih siswa ini, dalam bentuk kegiatan - kegiatan pelajaran tambahan, dan ekstrakurikuler. Hal ini sesuai dengan pendapat Dedi Supriyadi (1999) bahwa guru ideal harus mampu memberikan pelayanan pendidikan yang bermutu bagi siswa, diantaranya harus bertindak ibaratnya sebagai pelatih (coach) olahraga, yang lebih banyak membantu siswa dalam "permainan", dan permainan itu adalah belajar (game of learning).

Guru-guru SMP Negeri 1 Pageruyung juga telah bersikap sebagai sahabat yang senantiasa siap membantu siswa memecahkan permasalahannya. Sikap guru sebagai sahabat tersebut seperti yang diungkapkan oleh Dedi Supriyadi (1999) bahwa guru perlu bersikap sebagai konselor yang menjadi sahabat bagi siswa, teladan dalam pribadi yang mengundang rasa hormat dan keakraban dari siswa.

Berkenaan dengan guru harus menjadi teladan, maka guru-guru SMP Negeri 1 Pageruyung telah mampu menjadi teladan bagi siswa-siswanya, misalnya penampilan guru, layanan guru dan sebagainya.

Guru-guru SMP Negeri 1 Pageruyung telah melakukan pembimbingan belajar kepada siswa dalam memahami pelajaran. Guru-guru selama ini memang menggunakan cara-cara terbaik, agar materi pelajaran juga dapat tersampaikan dengan baik, sehingga para siswa dapat lebih mudah dalam memahami materi pelajaran. Hal itu oleh Dedi Supriyadi (1999) dikatakan bahwa guru harus bertindak sebagai manajer belajar, yakni membimbing siswanya belajar, mengambil prakarsa, dan mengeluarkan ide-ide terbaik yang dimilikinya.

Guru-guru SMP Negeri 1 Pageruyung juga telah belajar dari teman seprofesinya, untuk meningkatkan pembelajaran selanjutnya. Berkaitan dengan ini, bahwa guru-guru belajar dari teman seprofesinya, melalui MGMP. Melalui MGMP itulah diharapkan guru bisa belajar bersama teman seprofesinya, misalnya melalui model "team teaching" (Dedi Supriyadi, 1999).

Berdasarkan analisis data kuesioner siswa, maka dapat diketahui bahwa kategori hasil pengukuran aspek pelayanan pendidikan bermutu menunjukkan sebanyak 26 sampel 
berada pada kategori sangat tinggi (52\%). Sedangkan untuk kategori tinggi memiliki nilai sebesar $28 \%$ dengan $\mathrm{n}=14$ dan kategori sedang 10 sampel (20\%). Sedangkan berdasarkan analisis kuesioner guru, dapat diketahui bahwa kategori hasil pengukuran aspek pelayanan pendidikan bermutu menunjukkan 14 sampel berada pada kategori sangat tinggi (64\%). Sementara itu kategori tinggi memiliki nilai sebesar $36 \%$ dengan $n=8$. Berdasarkan hasil wawancara dan juga hasil angket tersebut diatas, maka dapat dikatakan bahwa tujuan program tunjangan profesi guru untuk meningkatkan pelayanan pendidikan bermutu di SMP Negeri 1 Pageruyung sudah tercapai.

\section{SIMPULAN DAN SARAN}

\section{Simpulan}

Berdasarkan pembahasan hasil penelitian ini, maka dapat disimpulkan sebagai berikut:

1) Martabat guru SMP Negeri 1 Pageruyung terangkat setelah mendapatkan tunjangan profesi. Adapun indikator martabat guru yang belum terpenuhi adalah kegiatan penelitian ilmiah.

2) Kompetensi guru SMP Negeri 1 Pageruyung meningkat setelah mendapatkan tunjangan profesi. Indikator kompetensi guru yang belum terpenuhi adalah: a. manajemen waktu pembelajaran di kelas belum efektif, karena guru belum bisa menggunakan waktu dengan semestinya sesuai RPP; b. ketrampilan bertanya guru untuk menggali pemahaman siswa belum dikuasai dengan baik oleh beberapa guru, dan c. pengembangan alat penilaian yang belum sesuai dengan tujuan pembelajaran.

3) Profesi guru di SMP Negeri 1 Pageruyung belum mengalami kemajuan setelah guru mendapatkan tunjangan profesi. Adapun indikator yang belum terpenuhi adalah kemampuan guru dalam mengkomunikasikan pemikiran-pemikirannya baik di lingkungan sekolah maupun di forum-forum ilmiah.

4) Mutu pembelajaran di SMP Negeri 1 Pageruyung meningkat setelah guru - gurunya mendapatkan tunjangan profesi. Indikator yang belum tercapai oleh guru adalah: a. dalam melakukan penilaian belum semua guru memberikan komentar tertulis pada ulangan atau tes yang diujikan kepada siswa; dan b. dalam proses pembelajaran, belum semua guru memberikan tugas kepada siswa untuk menulis atau membaca kembali materi yang telah dipelajari.

5) Pelayanan pendidikan di SMP Negeri 1 Pageruyung meningkat setelah gurugurunya mendapatkan tunjangan profesi.

\section{Saran}


Berdasarkan temuan hasil penleitian di atas maka dapat dikemukakan saran-saran sebagai berikut:

1) Bagi Kepala Sekolah. Kepala Sekolah hendaknya a) Terus memotivasi guru untuk selalu menjaga martabatnya, dengan rajin membaca, melakukan penelitian ilmiah dan mengikuti kegiatan ilmiah; b) mengadakan pembinaan secara intensif agar kompetensi guru meningkat, terutama pada kemampuan guru mengatur waktu pembelajaran di kelas, penguasaan ketrampilan bertanya dan pengembangan alat penilaian yang sesuai dengan tujuan pembelajaran; c) memfasilitasi dan memberi kesempatan pada guru agar dapat memajukan profesinya dengan cara mengikutkan guru pada kegiatan-kegiatan pelatihan karya tulis ilmiah; d) menciptakan kondisi agar guru berani mengungkapkan permasalahan pembelajaran yang dialaminya (supervisi klinis), sehingga guru mampu meningkatkan mutu pembelajarannya, dan e) mendorong guru untuk selalu bekerja secara profesional sehingga pelayanan pendidikan bermutu di SMP Negeri 1 Pageruyung senantiasa meningkat.

2) Bagi Guru. Guru hendaknya a) selalu menambah dan memperluas ilmu, wawasan dan keterampilanya dengan rajin membaca, melakukan penelitian ilmiah, mengikuti kegiatan ilmiah dan kegiatan keilmuan lainnya; b) terus meningkatkan kemampuan pengelolaan kelas terutama mengatur waktu pembelajaran di kelas, ketrampilan bertanya dan mengembangkan alat penilaian yang sesuai dengan tujuan pembelajaran: c) aktif mengikuti pelatihan penulisan karya tulis ilmiah, agar mampu melakukan penelitian ilmiah dan dapat mengkomunikasikan hasil penelitian yang dilakukan melalui forum-forum ilmiah maupun jurnal profesi; d) proaktif menyampaikan permasalahan pembelajaran yang dialami, sehingga kepala sekolah dapat memberikan supervisi klinis yang tepat, dan e) eningkatkan profesionalitas dalam bekerja, sehingga selalu dapat memberikan pelayanan pendidikan bermutu di SMP Negeri 1 Pageruyung.

\section{DAFTAR PUSTAKA}

Amat Jaedun. 2009. "Evaluasi Kinerja Profesional Guru”, Makalah. Universitas Negeri Yogyakarta.

Arni Muhammad. 2005. Profesi Kependidikan. Padang: UNP Press.

Badrun Kartowagiran, 2011. "Kinerja Guru Profesional”. Cakrawala Pendidikan, Universitas Negeri Yogyakarta.

Dedi Supriadi. 1999. Mengangkat Citra dan Martabat Guru. Yogyakarta: Adicita Karya Nusa.

Depdiknas. 2004. Kebijakan dan Pedoman Akreditasi Sekolah. Jakarta: Depdiknas. 
Depdiknas. 2008. "Sertifikasi Guru dalam Jabatan Tahun 2008", Pedoman Sertifikasi Guru dalam Jabatan melalui Penilaian Potofolio. Jakarta: Ditjen DIKTI

Eko Putro Widoyoko. 2009. "Evaluasi Program Pembelajaran", Panduan Praktis Bagi Pendidik dan Calon Pendidik. Yogyakarta: Pustaka Pelajar.

Ikke Dewi Sartika. 2002. Quality Service In Education, Edisi Khusus Untuk Kalangan Mahasiswa. Bandung: Kantor Yayasan Potensia.

Kemdikbud. 2013. Petunjuk Teknis Penyaluran Tunjangan Profesi Guru PNSD Melalui Mekanisme Transfer Daerah. Jakarta: Depdikbud.

Lyimo, Godrick Efraim. 2014. Analysis of Teachers' Low Payment in Tanzania: A Case Study of Public Secondary Schools in Moshi Rural District, International Journal of Education and Research Vol. 2 No. 2 February 2014

Meke, Elizabeth Selemani. 2013. Teacher Motivation and Implementation of Continuing Professional Development Programmes in Malawi. Fakultas Pendidikan Universitas Fort Hare, Afrika Selatan.

Moleong, Lexi, J. 2004. Metodologi Penelitian Kualitatif. Bandung: Remaja Rosda Karya.

Margana. 2014. Rekapitulasi Nilai Verifikasi Kinerja Guru Penerima Tunjangan Profesi, SMP N 1 Pageruyung Kabupaten Kendal.

Peraturan Pemerintah Nomor 19 Tahun 2005 tentang Standar Nasional Pendidikan. Jakarta: Depdiknas

Peraturan Pemerintah Nomor 74 Tahun 2008 tentang Guru. Jakarta: Depdiknas

Sudarwan Danim. 2012. Pengembangan Profesi Guru. Jakarta: Kencana Prenada Media Group.

Suharsimi Arikunto. 2007. Prosedur Penelitian, Suatu Pendekatan Praktik. Jakarta: Rineka Cipta.

Supriyoko. 2006. "Citra, Harkat, dan Martabat Guru”. Jurnal Karya Ilmiah Dosen. Jogjakarta: Amikom..

Undang-Undang Republik Indonesia Nomor 20 Tahun 2003 tentang Sistem Pendidikan Nasional. Jakarta: Lembaran Negara.

Undang-Undang Republik Indonesia Nomor 14 Tahun 2005 Tentang Guru dan Dosen, Semarang: CV Duta Nusindo.

Yamin Latief Tjokra. 2011. "Evaluasi Program Kegiatan Kelompok Kerja Guru Madrasah Ibtidaiyah (KKG-MI) Cemara Jaya di Lingkungan Kementerian Agama Kabupaten Halmahera Timur". Artikel, Kementerian Agama Provinsi Maluku Utara.

Yasbiati. 2010. "Pengaruh Persepsi Guru Tentang Sertifikasi Terhadap Kualitas Pembelajaran di SDN Nagarawangi 1 Tasikmalaya”. Jurnal Saung Guru, Vol.I No.1 